While pursuing the development of these glands opportunity was taken of proving that Engelmann's so-called "neuroid filaments" (Neuroidfasern) were not of a neural nature.

Under the heading "function" Schiemenz treats of some curious views that have been advanced by authors in regard to the different salivary glands of bees. Ramdohr at first mistook system II for an olfactory organ and system III for its continuation in open communication with the tracheae of the thorax. He later corrected this error. Fischer thought that system III was an "insect-lung." Wolff and Graber properly receive sharp criticism at the hands of Schiemenz because they thought that system IV was a gland for moistening an olfactory organ beneath the labrum, the place where Wolff, in his wild search for analogies between vertebrates and insects, had located the olfactory organ of the bee. Schiemenz regards the glands of system IV as used in the preparation of food, and the glands of system I as producing, in part at least, the nutrient fluid used for the larvae. The functions of the other systems still remain doubtful.

As an appendix the author describes and figures the structures of the antennae of Apis mellifica, since it is now settled that the antennae are the seat of the olfactory sense.

\title{
CONTRIBUTION TO THE KNOWLEDGE OF PARASITIC LIFE IN GALLS.
}

[Translated, with some change, from G. Fr. Möllers "Bidrag till kännedomen om parasitlifvet i galläpplen och dylika bildninger" (Entom. tidskr., 1882, årg. 3, p. 182-186).]

BY B : PICKMAN MANN, WASHINGTON, D. C.

In his work, Die ichneumonen der forstinsecten, bd. 2, p. $2 \mathrm{I} 7$ and 219 , Ratzeburg gives a list of all the parasites which Tischbein, Nördlinger, Reissig, and others had hatched from galls of species of Cynips and Nematus. Since however the list is very incomplete as regards our fauna I will here give a list of the parasites and inquilines which I have obtained from such gall-formations during several years' continuous investigations.

In the determination of the species I have followed exclusively Thomson's Hymenoptera Scandinaviae and Opuscula entomologica. Where the sex is not mentioned it is to be understood that both males and females were obtained, and where the quantity of specimens is not mentioned that a moderate number were obtained; (a) indicates an abundance, (aa) a great adundance, and ( $r$ ) a scarcity of specimens.

I. From galls of Cynips folii, collected in Scania, September I868, were raised, in March 1869:- Torymus viridissimus (r), T. cingulatus, T. Aavipes 9 (unique); in April :Synergus vulgaris; in May:-Eurytoma appendigaster $\&$ (unique).

2. From galls of Cynips longiventris, collected in Scania, September 
I875, were raised, in May $1876:-$ Torymus nigricornis $\$$ (unique), Syntomaspis cyanea, Synergus nervosus (a), Platytermus fasciculatus, Decatoma biguttata $\%(\mathrm{r})$.

3. From galls of Cynips terminalis, collected in Blekinge, July 1876 , were raised, in July 1876:- Torymus viridissimus (a), Synergus facialis, Decatoma biguttata $\$$, Torymus euchlorus (r), $T$. cingulatus $\$$ (unique), Piatytermus simplex (r), Cecidostiba truncata (r), Megastigmus dorsalis $\delta$ (unique); in February and March I877:-Olinx gallarum (aa); in March :--Syntomaspis saphirina (a), Megastigmus dorsalis ( $\mathrm{r}$ ) ; in May :Eupelmus urozonus (r), Cecidostiba rugifrons.

4. From galls of Cynips terminalis from Öland, collected in September I876, were raised, in February to April I 877 : - Syntomaspis saphirina (aa) ; in March : - Pimpla inanis o (r) ; in April to July:- Megastigmus dorsalis; in April:-Synergus nervosus (a), Tortrix (? Grapholitha puncticostana) (r), Cecidostiba rugifrons, larvae of Balaninus villosus (a), Eurytoma intermedia; in May:Eupelmus urozonus (a), Cecidomyia longicornis $\delta$ (rather rare), Cecidostiba truncata (r), C. collaris, Eupelmus azureus (rather rare); in June : - Tetrastichus terminalis $q$.

Remark. The small lepidoptera and diptera which occur here, as well as the coleopterous larvae, are inquilines. The little Pimpla has probably been raised as a parasite upon the tortrici- dae, as also presumably the Tetrastichus from the Cecidomyia, analogously with its related genus Oxymorpha, which lives parasitically on Cecidomyia fagi. The Eupelmus have perhaps lived as parasites in the Curculio-larvae.

5. From galls of Cynips gemmae, from Scania, autumn of 1876 , were raised, in March 1877:- Synergus vulgaris (a), Olinx gallarum (a), Syntomaspis saphirina (a).

6. From galls of Cynips (Spathegaster) baccarum, collected in Scania during April and May I876-1879, were raised, in May 1876:-Synergus apicalis (r), Figites anthomyiarum $q$ (unique); in June 1877:- Torymus viridissimus (a), Amblymerus crassicornis $\$$ (rather rare), A.pedunculi $\$$ (rather rare); in March 1879 :Olinx fulvicrus $\$$; in April:-Synergus thaumacerus of (unique); in July:- Torymus viridissimus (a), Eutelus heterotomus ơ (unique), $E$. collaris, Synergus vulgaris (a), Platytermus fasciculatus $\$(\mathrm{r})$, Ormyrus gastris $\delta$ (common) $\$(\mathrm{r})$.

7. From galls of Cynips (Trigonaspis) crustalis, collected in Scania, April I878 and 1879, were raised, in June I 878 : - Synergus thaumacerus (a); in April 1879: - Syntomaspis fastuosa (a) ; in July :-Synergus thaumacerus. Remark. At the end of April 1878 quite numerous individuals of Trigonaspis of both sexes came forth, whenever Synergus exterminated Syntomaspis; in 1879 not a single Trigonaspis came forth whenever they were exterminated by Syntomaspis, whose para- 
site Synergus was now present in small numbers.

8. From galls of Cynips (Andricus) inflator, from Scania, April I877, were raised in the same month:- Synergus (Sapholytus) connatus o ( $\mathrm{r}$ ).

9. From galls of Cynips (Andricus) curvator, collected in Scania, June I879, were raised, in July I 879: - Platytermus fasciculatus.

Io. From galls of Cynips (Andricus) ramuli, from Scania, June $\mathrm{I} 88 \mathrm{I}$, were raised, in July 188I:-Olinx gallarum (a), Eutelus tibialis \&, Decatoma incrassata $\&$ (unique).

I I. From galls of Cynips (Aulax) glechomae, from Scania, were raised, in April I882:- Torymus glechomae n. sp. $\&$ (2 specimens).

12. From galls of Cynips (Aulax) foveiger on Hieracium umbellatum, were raised, in 1882 :- Decatoma submutica (a).

I3. From bedeguar galls [Rhodites rosae] on Rosa canina, collected in Scania during March $\mathbf{I} 88 \mathrm{r}$ and April I 882, were raised, in May to July I88I : - Cynips (Rhodites) rosae o ( $\mathrm{r}$ ) 9 (a), Ortopelma luteolator (a); in May and June:-Habrocytus bedeguaris (r) ; in June and July :- Torymus bedeguaris ( $\mathrm{r}$ ) ; in April to June 1882 : - Ortopelma luteolator (a), Torymus bedeguaris (a) ; in May and June :Eurytoma pubicornis, Rhodites rosae. \& (r), Aulax brandti (aa).

14. From swelling on the branches of Salix capraea, collected near Stehag, in Scania, during March $\mathrm{I} 8 \mathrm{I}_{\mathrm{I}}$ and April I882, were raised, in Mav I88I :-
Nematus viduatus (r), Pimpla inanis $\delta(\mathrm{r}), P$. vesicaria $\delta$ (common) \& (unique), $P$. brevicornis, $P$. mandibularis (r) ; in May and June, Nematus pentandrae (a) ; in June:-Limneria chrysosticta (aa), Sympiezus sericeicornis $\delta$ (unique) ; in June and July :Habrocytus capreae (aa), Eurytoma salicis (a) ; in April I882:-Nematus pendandrae (a) ; in April and May:Limneria chrysosticta (a); in May and June:-Eurytoma salicis (a), Habrocytus capreae ( $\mathrm{r}$ ).

A part of the species of the genus Torymus and of the genera Syntomaspis and Megastigmus are constant parasites in galls on oak, like Ortopelma and Torymus bedeguaris in rose-galls and Limneria chrysosticta in willowgalls. The genera Synergus, Eurytoma and Decatoma are all secondary parasites, that is to say, they attack in their turn the parasites on gallformations and destroy them. The other pteromalini (Eutelus, Platytermus, Habrocytus, etc.) are probably also secondary parasites. In regard to Aulax brandti, on the other hand, which often occurs so numerously in bedeguars, it can hardly be considered as a parasite, since all its congeners form gall-like swellings on the branches of plants or live in swollen seed-capsules, but it may be considered to be an inquiline or the possible fellow-builder with Rhodites rosae. The Pimpla raised from willow galls of the year I 88 I have probably all lived parasitically on the larger Nematus viduatus. 

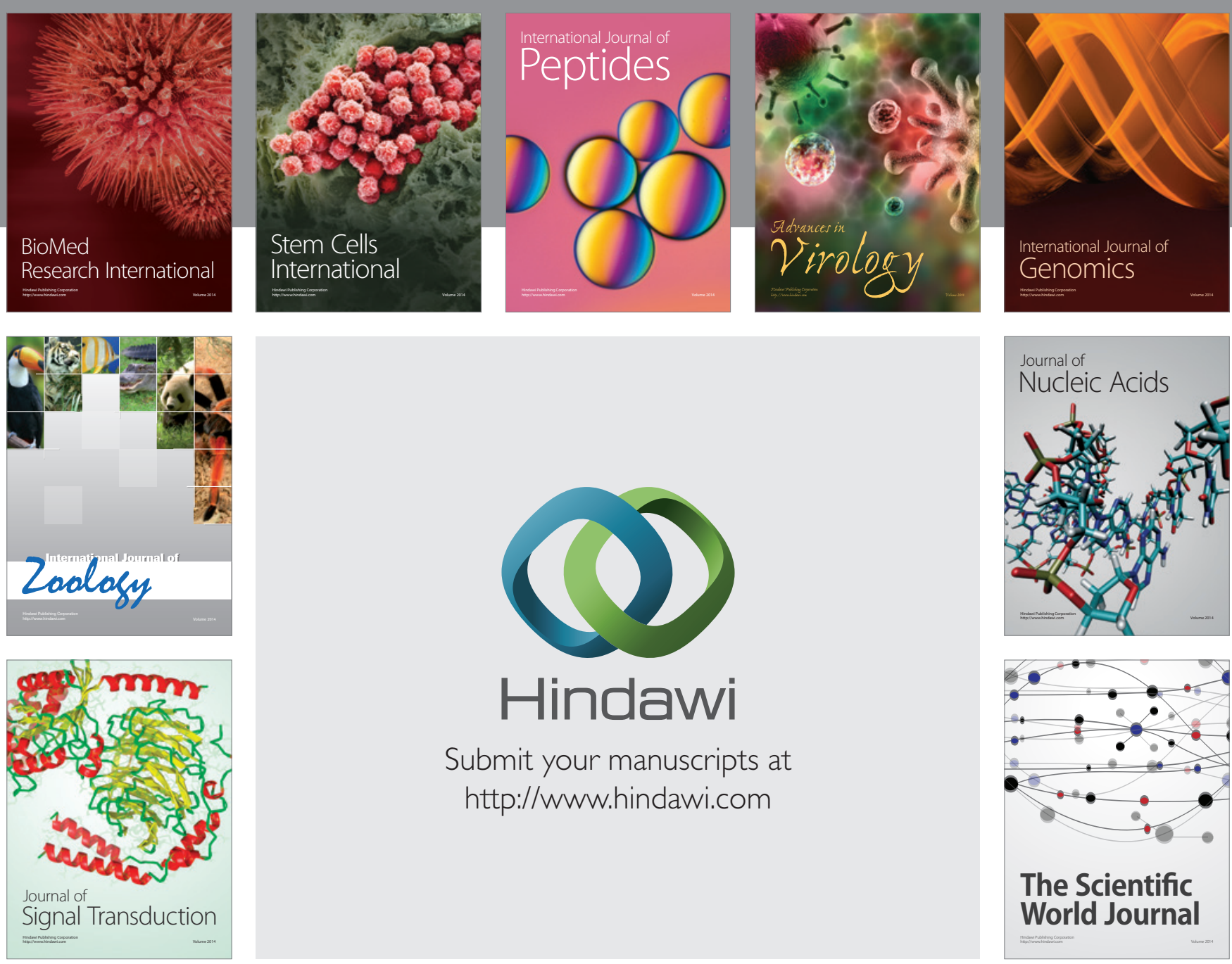

Submit your manuscripts at

http://www.hindawi.com
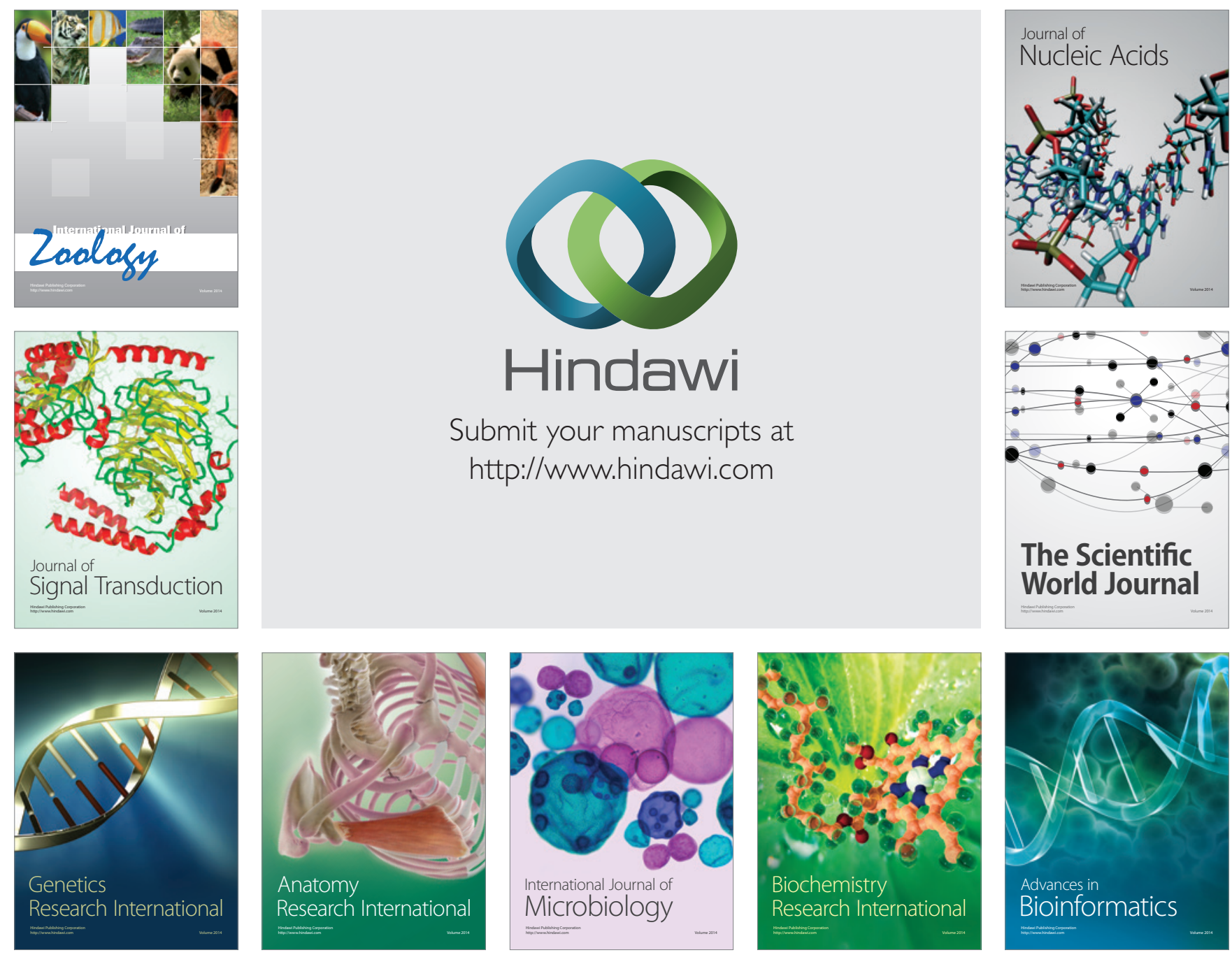

The Scientific World Journal
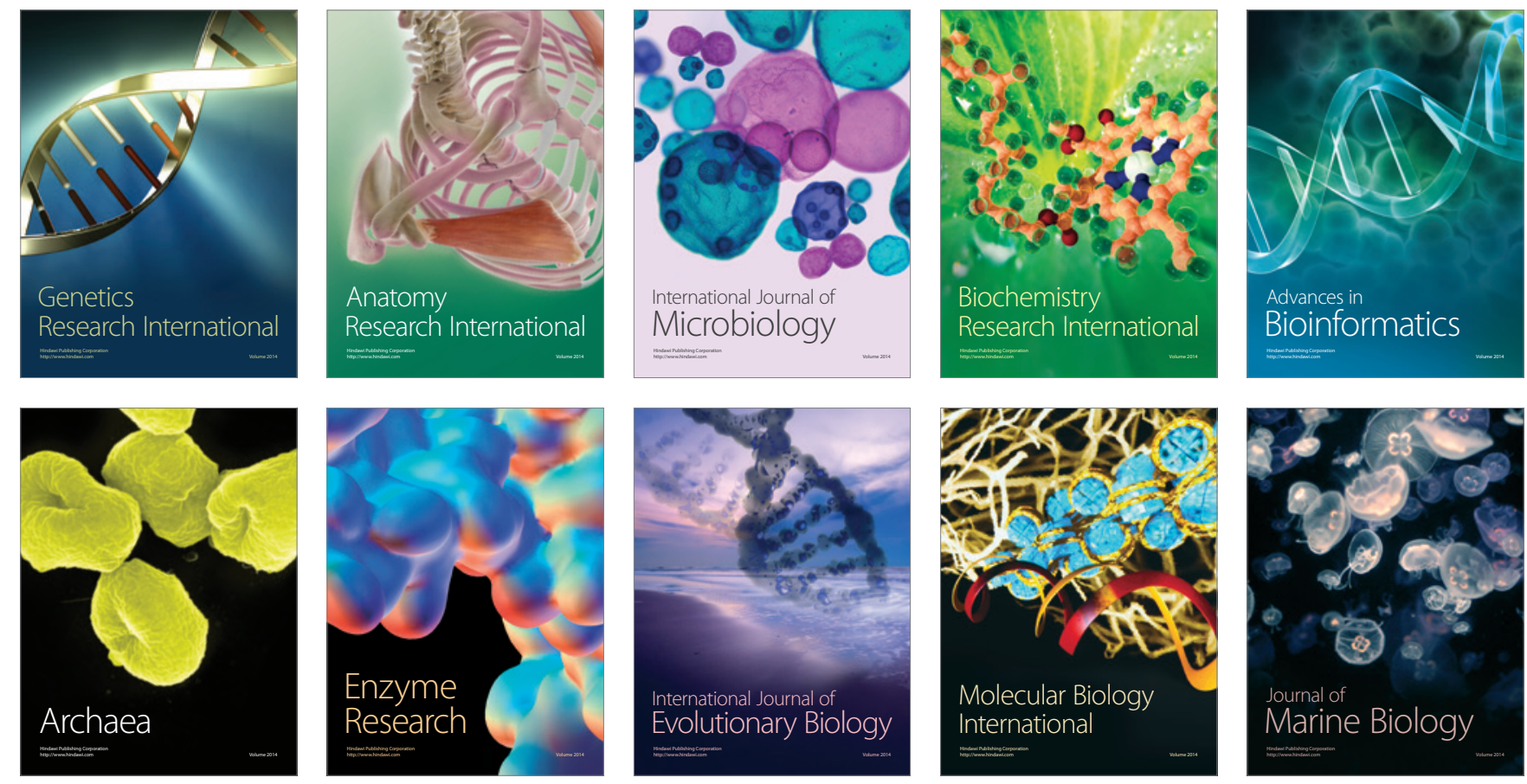